\section{Neglect of sports medicine}

F A d'Abreu, frcs. . . . . . . . . . . . . . 118

Penicillin-resistant gonococci

S Selwyn, MD, and M Bakhtiar, DPHARM. . 118

Treatment of children with diarrhoea and vomiting

D A McCredie, fracP............ 119

How dangerous is obesity?

J Womersley, mB............. 119

Motorcyclists' injuries

J G Avery, мғсм............. 119

Fellows of the Royal Society

L Mary Pickford, MRCS, FRS.

Shortage of anaesthetists

J L Craven, FRCS; J P Alexander, FFARCs;

P A Casey, MD; T R Austin, fFARCS.... . 120

How effective is measles immunisation?

M D Coulter, MB, and B M Jones, MB ... 120

Commitment to oncology

R G B Evans, FRCR, and others....... 121

Breath, alcohol, and the law

B M Wright, MB............

MRC treatment trial for mild

hypertension

$R$ W D Turner, FRCP........... 121

Severe thrombophlebitis with Praxilene

J Chamberlain, FRCSED; W Morris-Jones,

FRCS $\ldots \ldots \ldots \ldots \ldots \ldots \ldots \ldots \ldots \ldots \ldots \ldots \ldots \ldots \ldots$

Vitamin D "resistance" and the

bioavailability of calciferol tablets

C R Paterson, DM............. 122

Epilepsy and drowning in childhood

B G R Neville, MRCP............. 122

Combination chemotherapy in

metastatic breast cancer

W Mattson, MD; I H McIntosh, FRCs, and

others ................... 122
Cervical smears

D G H Sylvester, MD; O A N Husain,

FRCPATH ................ 12

Anaesthetic waste gas scavenging

systems

S Mehta, FFARCS.

Effect of antihypertensive drugs on growth hormone secretion

C Ferrari, MD, and others. .

Hospital inpatient provision for patients with dementia

J H Baron, FRCP.

Wound sepsis: effect of incidental appendicectomy

A V Pollock, FRcs, and Mary Evans, BA. .

Use of ritodrine in pregnant diabetics

T C G Smith, MB............... 12

Lithium carbonate in schizoaffective states

A J H McGennis, MRCPSYCH...

Microsomal enzymes in malnutrition

I T Gilmore, MRCP, and R P H Thompson, DM .................... 124

Management of hypertension

R M E Stone, BM.............

Drug compliance in hypertensive patients

patients
D A Persoff, MRCP, and Elaine Mason,

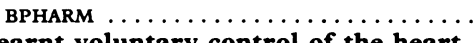

Learnt voluntary control of the heart

J Shackleton Bailey, MRCS.......... 125

Sulphinpyrazone in acute stuttering hemiparesis

G D O Lowe, MRCP, and R V Johnston,

MRCP $\ldots \ldots \ldots \ldots \ldots \ldots \ldots \ldots \ldots \ldots$
Colony-forming cells and myeloblasts in chronic granulocytic leukaemia

J M Goldman, MRCP, and others ....... 125

Alternatives to medicine

T L Jones, BA.............. 126
Beta-blockers and lipid metabolism

A Nilsson, MD, and others............ 126

Psychotropic drugs and road accidents

D P Wheatley, MD . .............. 126

Takayasu's disease and giant cell arteritis

-a single disease?

Diagnosing familial hypercholesterol-

aemia in childhood

D J Betteridge, MRCP, and others...... 127

Phenothiazine resistance

D L M McNeill, MRCPSYCH . . . . . . . . . 127

Reviving the hospital necropsy

J G Benstead, MD. .

oncentration of thyroxine-binding

globulin and the Thyopac-3 test

M C Davies, BSC, and H Allison, FRCPATH. . 128

Comparison of treatment with fast neutrons and photons

W M Ross, FRCR.

Prevention and health

I $M$ Richardson, fRCGP........... 128

Women in medicine

Anne J White, MB; Bridget C Rennie, MB. . 128

Preferred prescribing penalised

J N Stenhouse, MB.............. 129

A confidence trick

E S Field, FRCS.

Resignation by profession

M A Gilbert, MRCGP. . .

$\ldots \ldots \ldots .129$

Seniority allowance and large restricted

lists

$\mathrm{R} M$ Whittington, $\mathrm{BM} \ldots \ldots \ldots \ldots \ldots \ldots$
oreign graduates' entry to general

practice

J B Davis, MD................ 129

Administrative obstructionism

R L L Simmons, MRCOG............

National insurance contributions

M S Hall, FRCGP............... 129
Correspondents are urged to write briefly so that readers may be offered as wide a selection of letters as possible. So many are being received that the omission of some is inevitable. Letters should be signed personally by all their authors.

\section{Neglect of sports medicine}

SIR,-Your leading article on "Rugby injuries to the cervical cord" (18 June, p 1556), will, I hope, be read and studied by all those interested in sports medicine. There is far less official notice taken of unacceptable injuries in rugby than in boxing and horse racing. ${ }^{1}$ In these two sports all serious injuries have to be reported to the governing bodies and it is comparatively easy to compile annual statistics proving the efficacy of preventive measures instituted as a result of a study of these figures.

I do not feel that the figures quoted in your article, in the absence of compulsory notification of serious injuries in rugby to a national authority, give a complete picture of the unacceptable injuries in amateur rugby football, though such figures are obtainable for professional rugby. It is evident also that your article contains no figures at all for English rugby, and I cannot but feel, as you do, that exact figures from Wales, Scotland, Ireland, and South Africa are hard to find and are by no means complete.

Your article highlights the necessity for the appointment of properly qualified medical advisers to the various governing bodies in sport at a national level, with the authority to recommend measures to cut down, if not eliminate, the incidence of unacceptable injuries and death. Great Britain is the only member country of the EEC which has no centre for training in sports medicine in spite of the directive of the Council of Ministers of the EEC on 26 October 1973 that all countries in the European Community should establish these. It is perhaps high time that the Minister for Sport takes action in this matter to bring us in line with other nations.

FRANK D'ABREU

London NW1

1 d'Abreu, F A, Lancet, 1976, 1, 1241.

\section{Penicillin-resistant gonococci}

SIR,-Your leading article on the control of penicillinase-producing gonococci (25 June, p 1618) was both timely and informative. A misleading impression may, however, be given by the unqualified statement that cefuroxime is effective for treatment. This implies that the antibiotic is actually available for treatment, but it is in fact still at the stage of clinical trials. Moreover, the manufacturers (Glaxo Laboratories Ltd) can give no information about the date when the antibiotic is to be released for general use.

Of the available $\beta$-lactam antibiotics, twowhich you do not mention-retain full activity against penicillinase-producing gonococci. Cephalexin was shown by Percival et al ${ }^{1}$ to inhibit large inocula of penicillin-resistant gonococci at a concentration of $2.5 \mathrm{mg} / 1$ whereas the equivalent concentrations for cephaloridine, cloxacillin, and benzylpenicillin were 50,50 , and $>250 \mathrm{mg} / 1$ respectively. Cephalexin was also found to be at least four times as active as cephaloridine against penicillin-sensitive strains. Phillips $e t$ al have, however, shown cephradine to be even more active than cephalexin against penicillinsensitive strains, but as they used small inocula of gonococci their results appeared inconclusive for the more resistant organisms. We have shown that cephradine is even more stable than cephalexin in the presence of the TEM type of $\beta$-lactamase (penicillinase), which the most resistant gonococci produce, ${ }^{3}$ and cephradine also has the advantage of being available in injectable as well as oral formulations. We therefore await with interest the results of clinical studies using cephradine 